\title{
Epacris sparsa (Epacridaceae) reinstated
}

\author{
J.M. Powell and T.A. James
}

\begin{abstract}
Powell, J.M. and James, T.A. (National Herbarium of New South Wales, Royal Botanic Gardens, Sydney, NSW, Australia 2000) 1993. Epacris sparsa R. Br. (Epacridaceae) reinstated. Telopea 5(2): 375-380. The poorly known and inadequately described species, Epacris sparsa R. Br., is re-examined on the basis of recent collections of flowering and fruiting material. Notes on habitat and conservation status are given. It appears to be most closely related to E. impressa and E. longiflora.
\end{abstract}

\section{Introduction}

Epacris sparsa was described by Robert Brown (1810) from specimens collected from the Grose River area, New South Wales. The material was past flowering but the persistent long style and the Epacris-type ovary enabled him to place it correctly in the genus Epacris. In 1855 other specimens, again without flowers, were presented at the Paris Exhibition, as noted by Bentham (1869): 'Specimens without flower of the Sydney Woods collection, Paris Exhibition, 1855, n. 148, McArthur, said to be from a shrub of 10 to $15 \mathrm{ft}$., appear from the foliage to be this species, which, however, must remain in some measure doubtful till more perfect specimens have been examined.'

Efforts to collect further specimens were unsuccessful and consequently the species was relegated to a footnote as a doubtful species in the first census of New South Wales plants (Maiden \& Betche 1916). Maiden noted to Betche (correspondence 17 September, 1906) 'I have made a special [excursion] to the Grose River to find this [species] but could find nothing to com..[compare] with it. No one has found it since. I think it ought to [be] put in the Species dubiae [of] our Census'. Betche had, in fact, written to the British Museum (Natural History) about the species in 1906 and received a reply from J. Britten that the 'single specimen of Epacris sparsa is far from satisfactory ...' (correspondence J. Britten to E. Betche, October 16, 1906; held at NSW). He forwarded a fragment, however, and provided a transcript of Brown's manuscript description.

In the 1981 census of New South Wales plants it was listed as 'previous record not substantiated' (Jacobs \& Pickard 1981). Two specimens of Epacris sparsa, one fragmentary, the other with leaves and flowers, were collected in 1970 from the Grose River below Faulconbridge Point by L.H. Williams and D. Perrin respectively. Although deposited at the National Herbarium of New South Wales the significance of these specimens was not recognized at the time. A more recent collection, by T.A. James in 1991 from the Grose River at Avoca Vale Reserve, prompted further investigation and recognition of its significance, and the subsequent collection of flowering material allows more complete documentation of the species. 
Epacris sparsa $R . B r$.

Brown (1810: 551).

TyPe CitATION: '(J.) v.v.'

Lectotype (here designated): New South Wales: Central Coast: Grose River, R. Brown, 1803-5 (BM).

A slender erect shrub $30-90 \mathrm{~cm}$ high, lignotuberous; stems brown or red-brown, glabrous, with smooth to somewhat stringy bark; branchlets pinkish red-brown, villous, with prominent cup-shaped leaf scars. Leaves evenly spaced, erect to spreading (Figure 1a), narrowly ovate or elliptic (Figure 1f), 11.2-19.5 mm long, 2.4-5 mm wide, acute, apiculate or mucronulate, the tip 0.1-0.5 mm long; base cuneate; lamina flat (Figure 2a), concolorous, glabrous, with veins inconspicuous above, striate below, actinomorphic with some branching to the margin; margin with thicker cuticular rim abaxially, entire; petiole distinct, often reddish, 1-2.2 $\mathrm{mm}$ long, glabrous or pubescent. Young leaves pink-red. Flowers conspicuous, spreading to pendant (Figure 1a), solitary in upper axils; peduncles $2.4-3.2 \mathrm{~mm}$ long, villous, sparsely clothed with a few small narrowly ovate, acute bracts. Bracts subtending flower 10-12, scarious, increasing in size to sepals, ovate to sub-orbicular, $1.2-3 \mathrm{~mm}$ long, 1-1.6 mm wide, acute, striate, glabrous except for the minutely fringed margins. Sepals ovate-elliptic, 3.1-3.8 $\mathrm{mm}$ long, 1.4-1.6 mm wide, acute, glabrous except for the minutely fringed margins. Corolla-tube white, long-cylindrical and well exceeding sepals (Figure 1c-e), 16.2-20 $\mathrm{mm}$ long, 3.5-5 mm diameter, glabrous; lobes much shorter than tube, erect, ovate to sub-orbicular, 2.6-2.9 mm long, 2-2.5 mm wide, obtuse, glabrous. Anthers hidden in tube, rectilinear, reddish, $2-2.2 \mathrm{~mm}$ long, attached to the filament at or just above the midpoint; filaments terete, $0.2-0.5 \mathrm{~mm}$ long, inserted $1-1.5 \mathrm{~mm}$ below the base of the lobes. Ovary oblate (Figure 2c), $0.8-0.9 \mathrm{~mm}$ high, $1.2-1.3 \mathrm{~mm}$ wide, lobed, glabrous; style filiform, terete, $20.4-20.5 \mathrm{~mm}$ long, inserted to midpoint of ovary; stigma lobed, $0.2-0.25 \mathrm{~mm}$ high (Figure 2d); nectary $0.2-0.4 \mathrm{~mm}$ high, with shallowly lobed upper margin (Figure 2c). Capsule 1.4-1.8 mm high, 5-lobed (Figure 1b); seeds ovoid to sub-deltoid, $0.75-0.85 \mathrm{~mm}$ long, $0.4-0.65 \mathrm{~mm}$ wide, the surface evenly reticulate (Figure 2b,e).

FlowerING AND FRUITING TIME: Flowers May-June; capsules ripe in September.

Distribution: Known only from the lower Grose River area on the Central Coast of New South Wales.

HABITAT: Found at the base of rock faces or on rock platforms in the riparian flood zone, confined to pockets of damp sandy clay soil derived from exposed shale lenses between Hawkesbury Sandstone beds. The sites are frequently subject to high moisture from wind-driven spray and would be inundated during periods of high rainfall. Associated species include Tristaniopsis laurina, Leptospermum sp. aff. trinervium, Allocasuarina littoralis, Acacia longifolia, Grevillea sericea and Lomandra fluviatilis.

POPULATION SIZE: Four populations are known. The largest, of about 150 plants, occurs in the Avoca Vale Reserve, south-west of North Richmond, and a smaller population, of about 30 plants, is present near Faulconbridge in the Blue Mountains National Park. The other two populations are much smaller.

CONSERVATION: A conservation status of $2 \mathrm{VC}$ is appropriate following the criteria of Briggs \& Leigh (1988).

NoTES: Epacris sparsa appears to be most closely related to E. impressa Labill. and E. longiflora Cav. and more distantly related to E. calvertiana $\mathrm{F}$. Muell. These taxa all have long-tubed smooth-surfaced corollas (tube 1.5-5 times the sepal length), and corolla lobes much shorter than the tube (lobes $1 / 3-1 / 7$ th length of tube). The anthers are linear, \pm hidden in the throat, inserted 1-1.5 mm below the base of the 


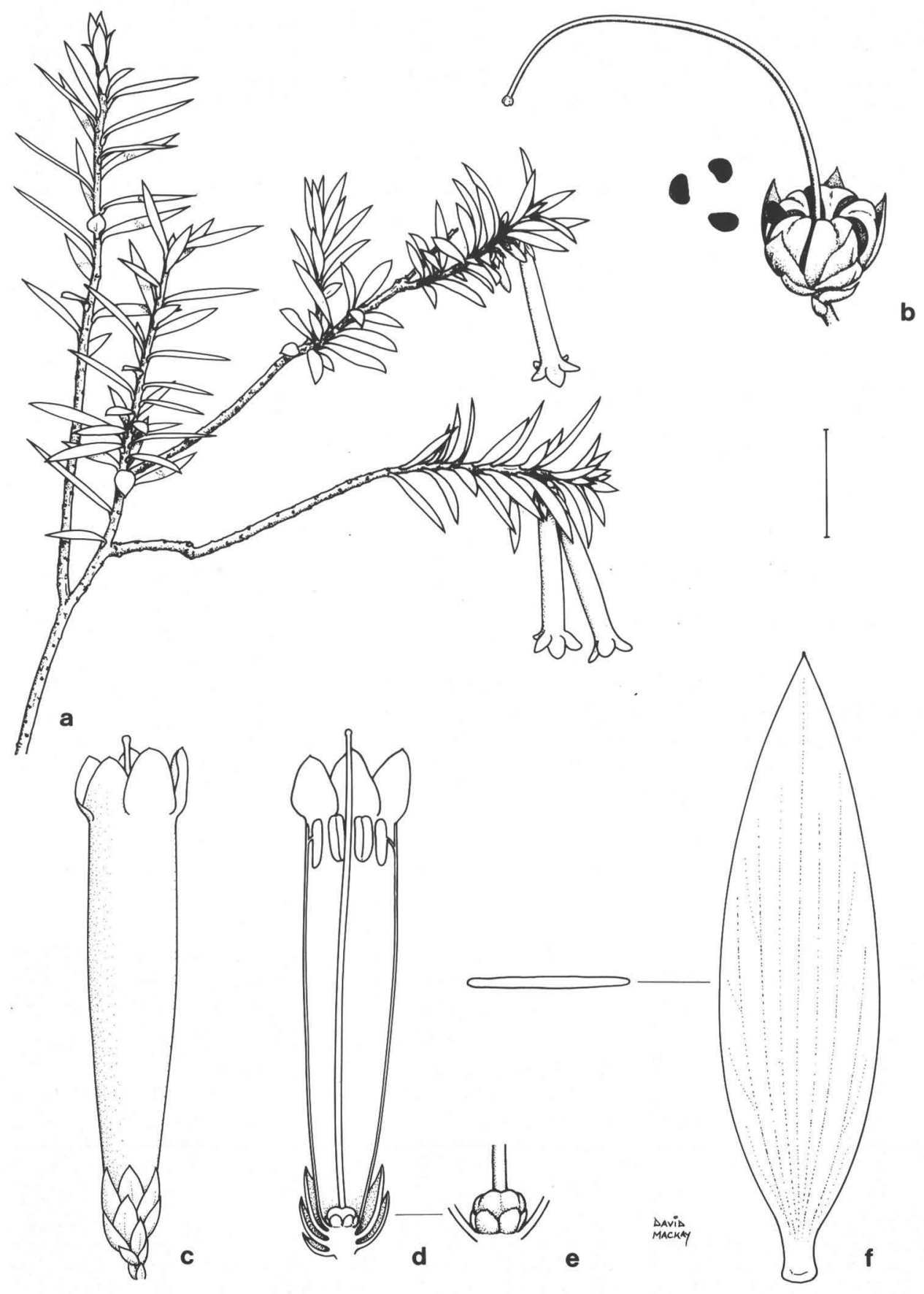

Figure 1. Flowering branch, flower and fruit structure of Epacris sparsa. a, Flowering branch (scale bar = $15 \mathrm{~mm}$ ); $\mathbf{b}$, fruit and seed (scale bar $=3 \mathrm{~mm}$ ); $\mathbf{c}$, $\mathbf{d}$, flower and flower section (scale bar $=5 \mathrm{~mm}$ ); e, detail of ovary and nectary (scale bar $=3 \mathrm{~mm}$ ); $f$, detail of leaf and transverse section (scale bar $=3 \mathrm{~mm}$ ). a,c-f, Powell 4817; b, James 1249 \& Kodela. 
corolla lobes; the filaments are very short, terete and attached to the anther above the midpoint. The ovary is oblate, the style longer than the tube and the stigma clearly lobed. The seeds are usually ovoid and the surface evenly reticulate. The main differences between the species (Table 1) are in leaf attributes, flower position and abundance, number of bracts subtending the flowers, style thickness, nectary margin, and capsule and seed size. Pollen tetrad size and surface ornamentation (Figure 3) provide further evidence of the relationship of $E$. sparsa to the other species listed. In tetrad size E. sparsa, with grains ranging $44.7-55.1 \mu \mathrm{m}$ (mean $50.5 \mu \mathrm{m}$ ), is intermediate in size between E. impressa (range 44.9-49.3, mean $47 \mu \mathrm{m}$ ), E. calvertiana (range 44.4-50.2, mean $46.3 \mu \mathrm{m}$ ) and E. longiflora, with grains ranging 54-60.1 $\mu \mathrm{m}$ (mean $57.6 \mu \mathrm{m}$ ). All have pollen tetrads with finely fossulate surfaces and smooth colpus margins. In E. sparsa the lumen is smaller than in E. longiflora but in both it reduces in size towards the poles and colpi, whereas in E. impressa and E. calvertiana lumen size is more constant over the entire surface.

Selected specimens: New South Wales: Central Coast: Grose River, Blue Mountains National Park, James 1316, Hind, Chapple \& Radford, 21 June 1992 (NSW), Perrin 1, May 1970 (NSW); Linden Creek, Blue Mountains National Park, James 1317, Hind, Chapple \& Radford, 21 June 1992 (NSW); Grose River, Avoca Vale Reserve, James 1249 \& Kodela, 15 Sep 1991 (NSW); Burralow Creek, Powell 4817, 23 May 1992 (NSW).
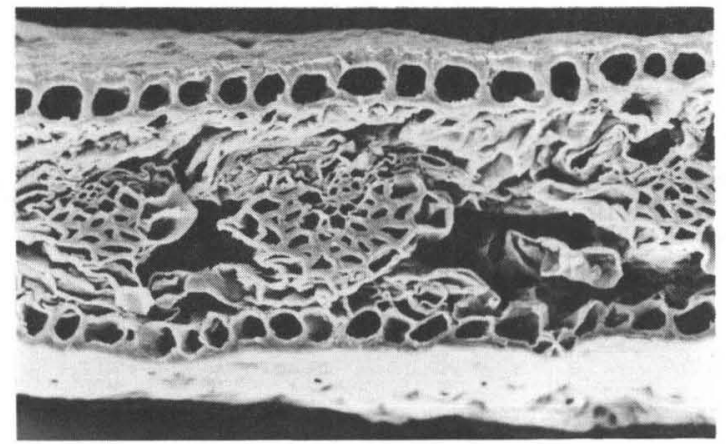

a

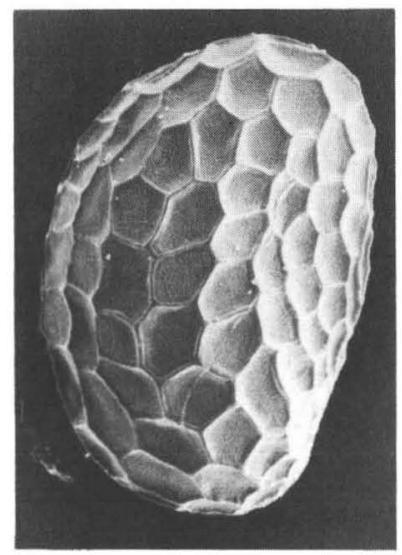

C

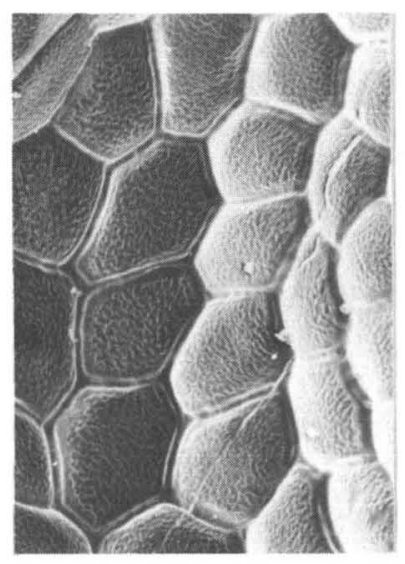

d

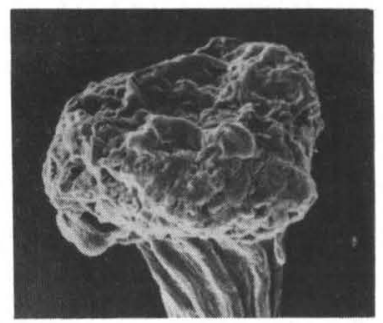

b

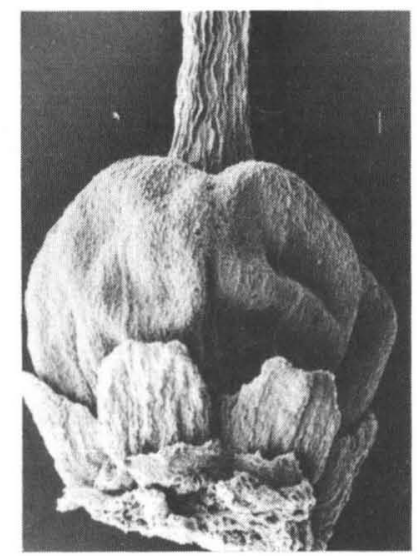

e

Figure 2. E. sparsa. Scanning electron micrographs of a, transverse section of leaf (x 250); b, stigma ( $x 80)$; c, seed ( $x 55)$; d, surface of seed ( $x 110)$; e, stylebase, ovary and nectary ( $x 40)$. 

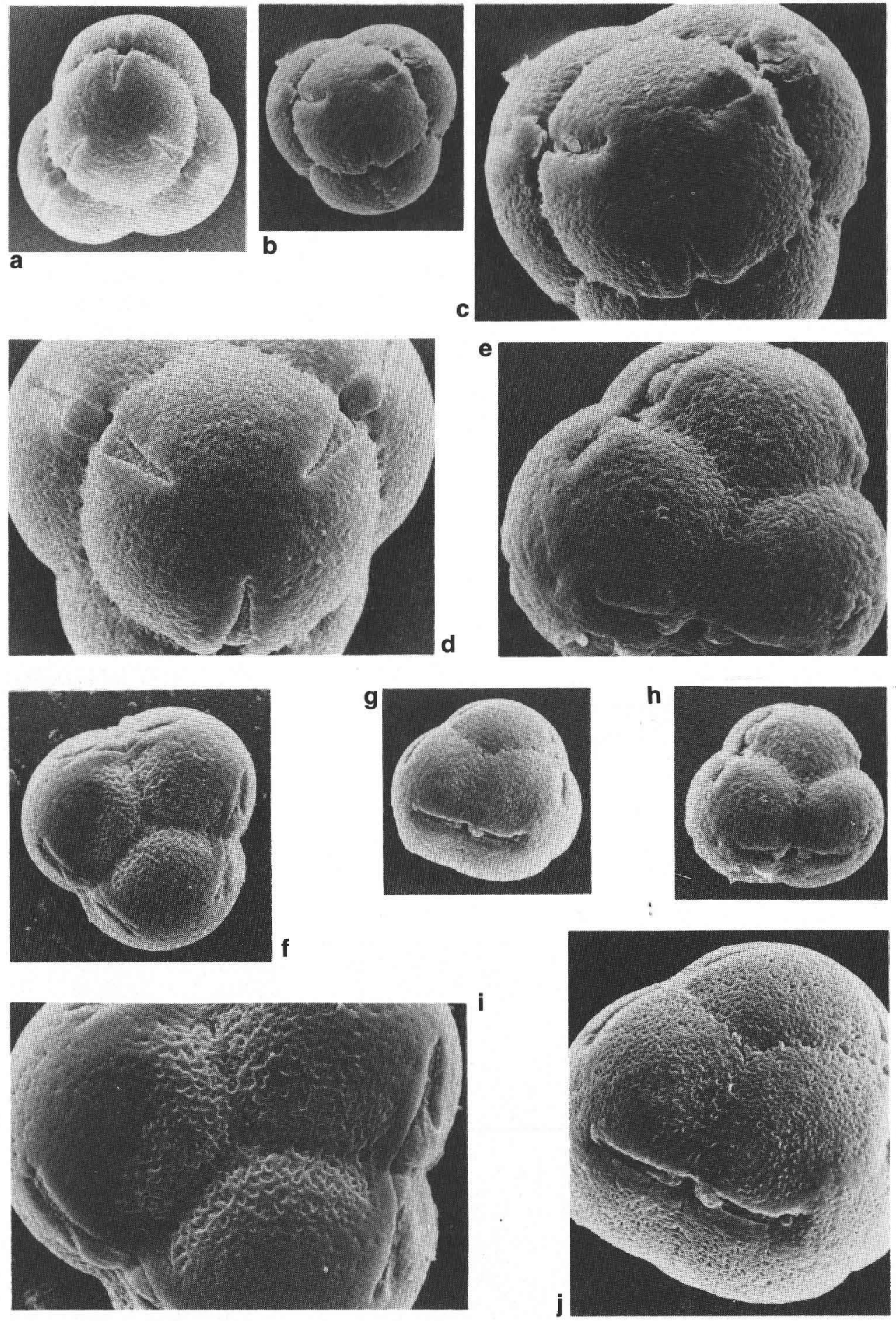

Figure 3. Pollen tetrads and pollen surface sculpture of $E$. sparsa and related species. $\mathbf{a}, \mathbf{b}, \mathbf{f}-\mathbf{h}$, tetrads, $\times 550 ; \mathbf{c}-\mathbf{e}, \mathbf{i}, \mathbf{j}$, tetrad surface detail, $\mathbf{x} 1100$. a,d, E. sparsa polar view; b,c, E. impressa polar view; e,h, E. sparsa equatorial view; f,i, E. longiflora equatorial view; $\mathrm{g}, \mathrm{j}$, E. calvertiana equatorial view. 
Table 1. Differences between E. sparsa and related species.

\begin{tabular}{|c|c|c|c|c|}
\hline Attribute & E. sparsa & E. impressa & E. longiflora & E. calvertiana \\
\hline Leaf shape & $\begin{array}{l}\text { narrowly } \\
\text { ovate } \\
\text { or elliptic }\end{array}$ & $\begin{array}{l}\text { ovate to } \\
\text { linear- } \\
\text { lanceolate }\end{array}$ & ovate & $\begin{array}{l}\text { elliptic to } \\
\text { ovate }\end{array}$ \\
\hline Leaf apex, tip & $\begin{array}{l}\text { acute, } \\
\text { apiculate or } \\
\text { mucronulate }\end{array}$ & $\begin{array}{l}\text { acute- } \\
\text { acuminate, } \\
\text { aristate }\end{array}$ & $\begin{array}{l}\text { acuminate, } \\
\text { aristate }\end{array}$ & subulate \\
\hline Leaf base & cuneate & truncate & $\begin{array}{l}\text { cordate or } \\
\text { obtuse }\end{array}$ & cuneate \\
\hline Leaf margin & $\begin{array}{l}\text { entire, } \\
\text { thickened }\end{array}$ & scabrous & scabrous & scabrous \\
\hline Petiole length (mm) & $\begin{array}{l}\text { 1-2.2, } \\
\text { distinct }\end{array}$ & $\begin{array}{l}<0.5 \\
\text { indistinct }\end{array}$ & $\begin{array}{l}0.6-1.1 \\
\text { distinct }\end{array}$ & $\begin{array}{l}\text { 0.9-1.4, } \\
\text { distinct }\end{array}$ \\
\hline $\begin{array}{l}\text { Flower position, } \\
\text { abundance }\end{array}$ & $\begin{array}{l}\text { spreading, } \\
\text { few }\end{array}$ & $\begin{array}{l}\text { spreading to } \\
\text { pendant, } \\
\text { many }\end{array}$ & $\begin{array}{l}\text { pendant, } \\
\text { many }\end{array}$ & $\begin{array}{l}\text { spreading, } \\
\text { few }\end{array}$ \\
\hline Number of bracts & $10-12$ & $15-24$ & $15-18$ & $20-26$ \\
\hline Flower colour & white & $\begin{array}{l}\text { white, pink } \\
\text { or red }\end{array}$ & $\begin{array}{l}\text { red-tubed, } \\
\text { white-lobed } \\
\text { or all white }\end{array}$ & $\begin{array}{l}\text { white, cream } \\
\text { or tube } \\
\text { pink to red }\end{array}$ \\
\hline Style thickness & filiform & $\begin{array}{l}\text { thick, inflated } \\
\text { above ovary }\end{array}$ & filiform & filiform \\
\hline Nectary margin & $\begin{array}{l}\text { shallowly } \\
\text { lobed, } \\
\text { and toothed }\end{array}$ & rounded & $\begin{array}{l}\text { irregularly } \\
\text { toothed }\end{array}$ & $\begin{array}{l}\text { irregularly } \\
\text { toothed }\end{array}$ \\
\hline Capsule height (mm) & $1.4-1.8$ & $2.2-2.7$ & $2.4-3.7$ & $2.6-3.0$ \\
\hline Mean seed size $(\mathrm{mm})$ & $0.81 \times 0.52$ & $0.76 \times 0.44$ & $0.74 \times 0.5$ & $0.58 \times 0.39$ \\
\hline
\end{tabular}

\section{Acknowledgements}

We should like to thank Peter Bankoff and Barbara Wiecek for help with the scanning microscopy and photographs respectively, and David Mackay for the diagrams.

\section{References}

Bentham, G. (1869) Flora Australiensis, vol. 4 (L. Reeve \& Co.: London).

Briggs, J.D. \& Leigh, J.H. (1988) Rare or Threatened Australian Plants. Australian National Parks \& Wildlife Service Special Publication no. 14.

Brown, R. (1810) Prodromus Florae Novae Hollandiae et Insulae Van Diemen, vol. 1 (J. Johnson \& Co.: London).

Jacobs, S.W.L. \& Pickard, J. (1981) Plants of New South Wales. A census of the cycads, conifers and angiosperms (Royal Botanic Gardens: Sydney).

Maiden, J.H. \& Betche, E. (1916) A Census of New South Wales Plants (Government Printer: Sydney). 